\title{
INTEGRATEd FRAMEWORK TO MODEL DATA WITH Business PROCESS AND BUSINESS RULES
}

\author{
Rajeev Kaula \\ Computer Information Systems Department, Missouri State University, Springfield, Mo, \\ USA
}

\begin{abstract}
Data modeling is an approach to model data by mapping operational tasks iteratively, while associated guidelines are either partly mapped in the data model or expressed through software applications. Since an organization is a collection of business processes, it is essential that data models utilize such processes to facilitate data modeling. Also, data models should incorporate guidelines for completing operational tasks through the concept of business rules. This paper outlines a unified framework on database modeling and design based on business process concepts that also incorporates business rules impacting business operations. The paper focuses on the relational database and its primary mode of conceptual modeling in the form of an entity relationship model. Concepts are illustrated through Oracle's database language $P L / S Q L$ and its Web variant PL/SQL Server Pages.
\end{abstract}

\section{KEYWORDS}

Data Modeling, Entity Relationship Model, Relational Model, Business Process, Business Rules, Oracle, $P L / S Q L$ Server Pages

\section{INTRODUCTION}

Data modeling is an iterative approach to model data utilized within an organization. It generally requires an understanding of business working from the perspective of (i) how operational tasks are performed, and (ii) what guidelines exist for completing such tasks. Over the years many data models have emerged like hierarchical, network, object, relational, and so on [4, 6, 9, 20, 21]. All of these models emphasize mapping of operational tasks iteratively, while associated guidelines are either partly mapped in the data model or expressed through software applications.

An alternative approach is to perform data modeling by integrating the two perspectives through the concept of business rules and business process. Since an organization is a collection of business processes [19], it is essential that data models utilize such processes to facilitate data modeling. Also, data models should incorporate guidelines for completing operational tasks through the concept of business rules [16, 10, 24, 25].

A business process is a sequence of structured activities performed to accomplish a business task such as processing a customer's order. It is often visualized through a diagram referred as a business process model $[1,2,18,19,22,27,28,29]$. Technically a business process transforms a set of inputs into a set of outputs in the form of some product or service for another person or business process that can span functional areas and cross organizations. As business processes are based on how work is done in an organization, they enable a good understanding of how data impacts business activities and operations.

While a business process can show the steps involved in the completion of a business task, the guidelines for completing the task are equally important to enhance the richness of the data model

DOI: $10.5121 / \mathrm{ijdms} .2016 .8601$ 
International Journal of Database Management Systems ( IJDMS ) Vol.8, No.6, December 2016

like cardinality specifications. Traditionally some of the guidelines were ascertained during the requirement phase of data modeling. However, it is important to incorporate these guidelines in the data model to ensure that it is a true representation of data requirements of the business.

For instance, suppose there are two entity types apartment and rental associated with "create rental" business process in an apartment complex business. Now, suppose there is a guideline that only those apartments that have no complaints pending should be rented. This guideline even though involves a complaints entity type, also impacts how an instance of rental entity type will be created. Including such specification in a data model provides a more comprehensive mapping of business operations.

Business rules by definition are guidelines that are an abstraction of the policies and practices of business operations. Business rules reflect the decisions needed to accomplish business policy and objectives of an organization [7, 8, 10,23]. Business rules specification enables an organization to better understand its operating environment, along with the ability to assert business structure, control and influence over organizational tasks [23].

Business rules are often developed as an addendum to transactional database development $[7,8]$. They are analyzed from the perspective of either extending an entity relationship model, or protect integrity within a relational database, or assist in the modeling of applications using events to invoke them [3, 10, 23]. Business rules systems have also been developed that are separate systems that assist in the management and execution of business rules pertaining to computational and integrity validation of business logic [10]. Even though business rules represent guidelines for business operations, they are also an abstraction of business requirements [17] that can be adapted to express data needs as well as its utilization to facilitate business process working [11, $12,13,14,24,26]$.

The objective of this paper is to outline a unified framework on database modeling and design based on business process concepts that also incorporates business rules impacting business operations. The paper focuses on the relational database and its primary mode of conceptual modeling in the form of an entity relationship model (ER model). Business rules concepts for data modeling and their derivation from business processes are outlined next, followed by their transformation into database design. The paper utilizes Oracle's database language PL/SQL and its Web variant PL/SQL Server Pages to illustrate the concepts.

\section{Business Rules For DATA MODELiNG}

Every organization has certain guidelines referred to as business rules that impact the entire business process. Some of the guidelines or rules may be associated with a specific business process activity, while others may impact the entire business process operations. There are many classes of business rules $[11,12,13,14,24,26]$ that define or constrain data as it impacts the business process. These statements can then be utilized to outline database entity types, their constraints, along with logic derivations that facilitate business process operations. Such business rules can be placed in four categories:

\section{Business Terms}

The most basic element of a business rule is the definition of business terms that are relevant to business process operations. These definitions are associated with terms that describe how people think and talk about things. For instance, "customer" and "apartment" are business terms that are relevant to a "create rental" business process for an apartment complex. Such terms can be represented as entity types in a conceptual data model. 


\section{Facts}

Business rules can also describe the nature or operating policies of a business process in terms of the facts that relate business terms to each other. Such business rules are represented as relationships, attributes, and generalization structures in a conceptual data model. For instance, a business rule statement like "a customer can place a sales order" represents a relationship among entity types customer and sales_order in a "sales order" business process. Similarly, a business rule statement like "a tenant must sign a rental agreement" represents a relationship among entity types tenant and rental in a "create rental" business process.

\section{Constraints}

Every organization has guidelines in the form of business rules that specify constraints on business process behavior in some way. Such business rules specify constraints on the data pertaining to the behavior within the entity types of a conceptual data model. A constraint is a condition that determines what values an attribute or relationship can or must have. Constraints category can be expressed either through attribute constraints, cardinality constraints, or some database program unit logic. For instance, a business rule statements like "every tenant automobile must have a valid license number" or "a rental agreement must be have only one employee or staff associated with it" represents constraints on tenant_auto and rental entity types respectively within a "create rental" business process.

\section{Derivations}

Business rules also define how a fact in one form may be transformed into some other knowledge or derived fact to support business process operations. For instance, a business rule statement like "no apartment should be rented if there are complaints pending on the apartment" illustrates how the status of apartment complaints effects the completion of "create rental" business process and its impact on rental entity type. In other words, the creation of a rental is derived from facts pertaining to apartment complaints entity type. Such business rules may affect the business logic of the "create rental" business process and hence may be expressed as database triggers or some database program unit.

\section{Business Process Derived Business Rules Prototype}

Three simplified business process scenarios from a public library environment are outlined now along with associated business rules having BR prefix. The diagrams follow the BPMN 2.0 notations [http://www.bpmn.org/]. To develop a unified framework that combines business rules with business process for database design, a business rules dictionary is proposed that can be stored in database for reference and maintenance.

\section{Get Library Card}

This operational task lists the sequence of activities for getting a library card for borrowing books as shown in Figure 1. Some of the business rules associated with the business process are listed in Table 1 below the business process diagram. In the table, along with the business rules, the category to which each rule belongs as outlined in section 2 is also included. 
International Journal of Database Management Systems ( IJDMS ) Vol.8, No.6, December 2016

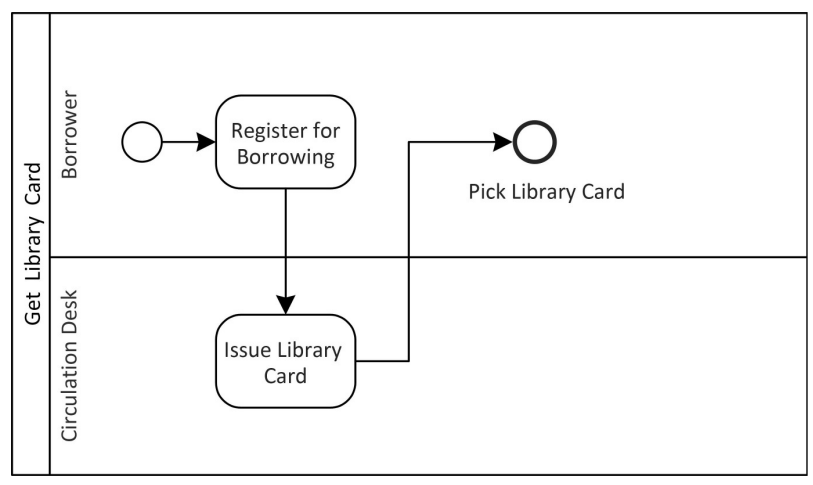

Figure 1. Get Library Card Business Process

Table 1. Get Library Card Business Rules

\begin{tabular}{|l|l|c|}
\hline $\begin{array}{l}\text { Business } \\
\text { Rules ID }\end{array}$ & Business Rules Description & $\begin{array}{l}\text { Business Rules } \\
\text { Category }\end{array}$ \\
\hline BR-1 & Terms Borrower, Library Card relevant for library. & 1,2 \\
\hline BR-2 & $\begin{array}{l}\text { Every borrower has to register their details before } \\
\text { borrowing any book from the library. }\end{array}$ & \\
\hline BR-3 & $\begin{array}{l}\text { Registration can be done online or by visiting a } \\
\text { branch of the local library. }\end{array}$ & \\
\hline BR-4 & $\begin{array}{l}\text { Once the registration is processed a library card is } \\
\text { issued. }\end{array}$ & \\
\hline BR-5 & $\begin{array}{l}\text { The library will issue only one library card per } \\
\text { borrower. }\end{array}$ & \\
\hline & & 4 \\
\hline BR-6 & Cancel library card if not picked in a week. & \\
\hline
\end{tabular}

\section{Acquire Books}

This operational task lists the sequence of activities for acquiring books from publishers as shown in Figure 2. Some of the business rules associated with the business process are listed in Table 2 below the business process diagram. In the table, along with the business rules, the category to which each rule belongs as outlined in section 2 is also included.

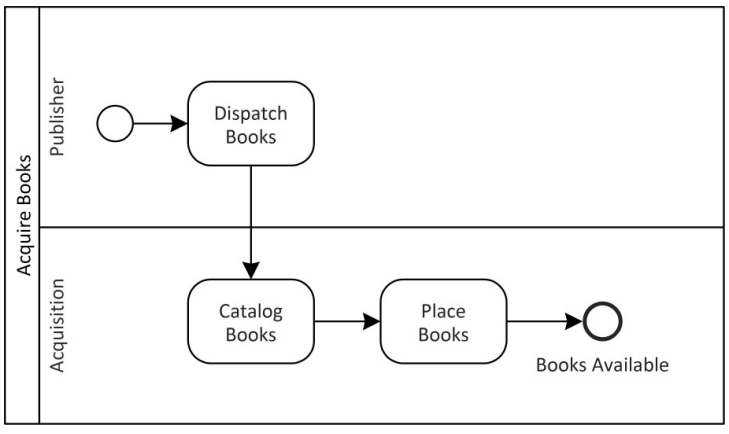

Figure 2. Acquire Books Business Process 
International Journal of Database Management Systems ( IJDMS ) Vol.8, No.6, December 2016

Table 2. Acquire Books Business Rules

\begin{tabular}{|l|l|c|}
\hline $\begin{array}{l}\text { Business Rules } \\
\text { ID }\end{array}$ & Business Rules Description & $\begin{array}{l}\text { Business Rules } \\
\text { Category }\end{array}$ \\
\hline BR-1 & Terms Book, Publisher, Author relevant for library. & 1,2 \\
\hline BR-2 & A book will have an associated publisher. & 2 \\
\hline BR-3 & $\begin{array}{l}\text { A book may have one publisher, but a publisher may } \\
\text { publish multiple books. }\end{array}$ & 2 \\
\hline BR-4 & A book is written by one or more authors. & 2 \\
\hline & An author is always associated with one or more books. & \\
\hline BR-5 & $\begin{array}{l}\text { No shipping charges paid if more than 5 books from } \\
\text { publisher per order }\end{array}$ & 2 \\
\hline BR-6 & \multicolumn{2}{|c|}{4} \\
\hline
\end{tabular}

\section{Borrow Book from Library}

This operational task lists the sequence of activities for borrowing books from library as shown in Figure 3. Some of the business rules associated with the business process are listed in Table 3 below the business process diagram. In the table, along with the business rules, the category to which each rule belongs as outlined in section 2 is also included.

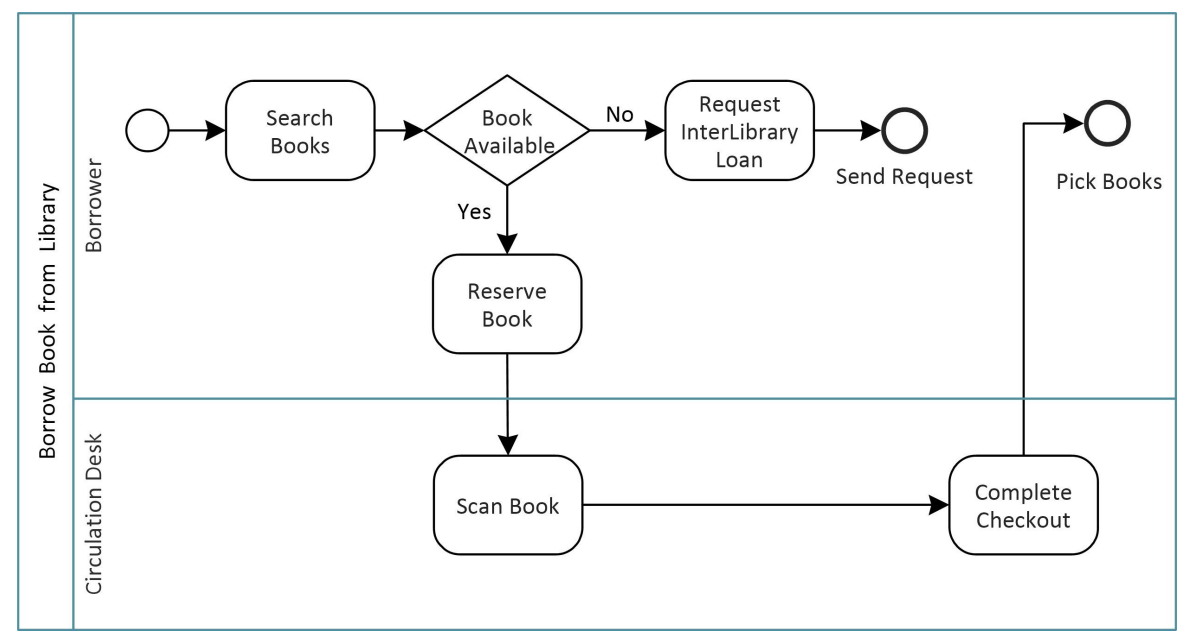

Figure 3. Borrow Book from Library Business Process 
International Journal of Database Management Systems ( IJDMS ) Vol.8, No.6, December 2016

Table 3. Borrow Book From Library Business Rules

\begin{tabular}{|c|c|c|}
\hline $\begin{array}{l}\text { Business Rules } \\
\text { ID }\end{array}$ & Business Rules Description & $\begin{array}{l}\text { Business Rules } \\
\text { Category }\end{array}$ \\
\hline BR-1 & $\begin{array}{l}\text { Terms Reservation, Checkout, Book, } \\
\text { Interlibrary Loan relevant to library. }\end{array}$ & 1,2 \\
\hline BR-2 & $\begin{array}{l}\text { Each reservation will be associated with only } \\
\text { one library card. }\end{array}$ & 2 \\
\hline BR-3 & A reservation can include one or more books. & 2 \\
\hline BR-4 & A book can be part of many reservations. & 2 \\
\hline BR-5 & $\begin{array}{l}\text { A borrower can make many reservations } \\
\text { through their library card. }\end{array}$ & 2 \\
\hline BR-6 & $\begin{array}{l}\text { Each book will have a separate Interlibrary } \\
\text { loan request. }\end{array}$ & 2 \\
\hline BR-7 & $\begin{array}{l}\text { A borrower may checkout books from multiple } \\
\text { reservations. }\end{array}$ & 2 \\
\hline BR-8 & $\begin{array}{l}\text { A checkout will be associated with only one } \\
\text { library card. }\end{array}$ & 2 \\
\hline BR-9 & $\begin{array}{l}\text { A checkout will be associated with one or more } \\
\text { books. }\end{array}$ & 2 \\
\hline BR-10 & $\begin{array}{l}\text { Deny checkout any borrowed book past return } \\
\text { date. }\end{array}$ & 4 \\
\hline BR-11 & Deny checkout if fines pending. & 4 \\
\hline BR-12 & $\begin{array}{l}\text { Borrowers can view the books available online, } \\
\text { and then reserve the books for borrowing or } \\
\text { else submit an interlibrary loan request. }\end{array}$ & 4 \\
\hline BR-13 & $\begin{array}{l}\text { Borrowers borrow books through the checkout } \\
\text { activity at Circulation desk. }\end{array}$ & 4 \\
\hline
\end{tabular}

\subsection{BUSINESS RULES DiCTIONARY}

To ensure the binding of operational logic with database structure as expressed through business rules for each business process, a business rules dictionary is proposed that contains the collection of all business rules for various business processes in an organization. Such a dictionary ensures consistency of the ensuing data model with business process operations. Table 4 shows the business rules dictionary for the above three business process diagrams. The business rules have now been sequenced across the three business processes through a Dictionary ID.

One new feature in the business rules dictionary will be the specification of the type of impact a business rule has on database design. Such an impact can be expressed as logic or design. Design impact implies that the business rule facilitates the design of the data model. The logic impact implies that the business rules should be incorporated as a database program unit in the form of a procedure, function, trigger, or package. Representation of business rules impact complements a database specific perspective of business processes in the form of an integrated and unified framework. 
International Journal of Database Management Systems ( IJDMS ) Vol.8, No.6, December 2016

Table 4. Business Rules Dictionary

\begin{tabular}{|c|c|c|c|c|c|}
\hline $\begin{array}{l}\text { Dictionary } \\
\text { ID }\end{array}$ & $\begin{array}{c}\text { Business } \\
\text { Process } \\
\text { Name }\end{array}$ & $\begin{array}{l}\text { Business } \\
\text { Rules ID }\end{array}$ & Business Rules Description & $\begin{array}{l}\text { Impac } \\
\text { t Type }\end{array}$ & $\begin{array}{l}\text { Impact } \\
\text { Entity } \\
\text { Types }\end{array}$ \\
\hline BRD-1 & $\begin{array}{l}\text { Get } \\
\text { Library } \\
\text { Card }\end{array}$ & BR-1 & $\begin{array}{l}\text { Terms Borrower, Library Card } \\
\text { relevant for library. }\end{array}$ & Design & $\begin{array}{l}\text { Borrower, } \\
\text { Library } \\
\text { Card }\end{array}$ \\
\hline BRD-2 & & BR-2 & $\begin{array}{l}\text { Every borrower has to re gister } \\
\text { their details before borrowing } \\
\text { any book from the library. }\end{array}$ & Logic & Borrower \\
\hline BRD-3 & & BR-3 & $\begin{array}{l}\text { Registration can be done online } \\
\text { or by visiting a branch of the } \\
\text { local library. }\end{array}$ & Logic & Borrower \\
\hline BRD-4 & & BR-4 & $\begin{array}{l}\text { Once the registration is } \\
\text { processed a library card is } \\
\text { issued. }\end{array}$ & Logic & $\begin{array}{l}\text { Borrower, } \\
\text { Library } \\
\text { Card }\end{array}$ \\
\hline BRD-5 & & BR-5 & $\begin{array}{l}\text { The library will issue only one } \\
\text { library card per borrower. }\end{array}$ & Design & $\begin{array}{l}\text { Borrower, } \\
\text { Library } \\
\text { Card }\end{array}$ \\
\hline BRD-6 & & BR-6 & $\begin{array}{l}\text { Cancel library card if not picked } \\
\text { in a week. }\end{array}$ & Logic & $\begin{array}{l}\text { Borrower, } \\
\text { Library } \\
\text { Card }\end{array}$ \\
\hline BRD-7 & $\begin{array}{l}\text { Acquire } \\
\text { Books }\end{array}$ & BR-1 & $\begin{array}{l}\text { Terms Book, Publisher, Author } \\
\text { relevant for library. }\end{array}$ & Design & $\begin{array}{l}\text { Book, } \\
\text { Author, } \\
\text { Publisher }\end{array}$ \\
\hline BRD-8 & & BR-2 & $\begin{array}{l}\text { A book will have an associated } \\
\text { publisher. }\end{array}$ & Design & $\begin{array}{l}\text { Book, } \\
\text { Publisher }\end{array}$ \\
\hline BRD-9 & & BR-3 & $\begin{array}{l}\text { A book may have one publisher, } \\
\text { but a publisher may publish } \\
\text { multiple books. }\end{array}$ & Design & $\begin{array}{l}\text { Book, } \\
\text { Publisher }\end{array}$ \\
\hline BRD-10 & & BR-4 & $\begin{array}{l}\text { A book is written by one or } \\
\text { more authors. }\end{array}$ & Design & $\begin{array}{l}\text { Book, } \\
\text { Author }\end{array}$ \\
\hline BRD-11 & & BR-5 & $\begin{array}{l}\text { An author is always associated } \\
\text { with one or more books }\end{array}$ & Design & $\begin{array}{l}\text { Book, } \\
\text { Author }\end{array}$ \\
\hline BRD- 12 & & BR-6 & $\begin{array}{l}\text { No shipping charges paid if } \\
\text { more than } 5 \text { books from } \\
\text { publisher per order }\end{array}$ & Logic & $\begin{array}{l}\text { Book, } \\
\text { Publisher }\end{array}$ \\
\hline BRD-13 & $\begin{array}{l}\text { Borrow } \\
\text { Book } \\
\text { from } \\
\text { Library }\end{array}$ & BR-1 & $\begin{array}{l}\text { Terms Reservation, Checkout, } \\
\text { Book, Interlibrary Loan re levant } \\
\text { to library. }\end{array}$ & Design & $\begin{array}{l}\text { Reservation, } \\
\text { Checkout, } \\
\text { Book, } \\
\text { Interlibrary } \\
\text { Loan }\end{array}$ \\
\hline
\end{tabular}


International Journal of Database Management Systems ( IJDMS ) Vol.8, No.6, December 2016

\begin{tabular}{|c|c|c|c|c|}
\hline BRD-14 & BR-2 & $\begin{array}{l}\text { Each reservation will be } \\
\text { associated with only one library } \\
\text { card. }\end{array}$ & Design & $\begin{array}{l}\text { Reservation, } \\
\text { Library } \\
\text { Card }\end{array}$ \\
\hline BRD-15 & BR-3 & $\begin{array}{l}\text { A reservation can include one or } \\
\text { more books. }\end{array}$ & Design & $\begin{array}{l}\text { Reservation, } \\
\text { Book }\end{array}$ \\
\hline BRD-16 & BR-4 & $\begin{array}{l}\text { A book can be part of many } \\
\text { reservations. }\end{array}$ & Design & $\begin{array}{l}\text { Reservation, } \\
\text { Book }\end{array}$ \\
\hline BRD-17 & BR-5 & $\begin{array}{l}\text { A borrower can make many } \\
\text { reservations through their library } \\
\text { card. }\end{array}$ & Design & $\begin{array}{l}\text { Reservation, } \\
\text { Borrower }\end{array}$ \\
\hline BRD-18 & BR-6 & $\begin{array}{l}\text { Each book will have a separate } \\
\text { Interlibrary loan request. }\end{array}$ & Design & $\begin{array}{l}\text { Book, } \\
\text { Interlibrary } \\
\text { Loan }\end{array}$ \\
\hline BRD-19 & BR-7 & $\begin{array}{l}\text { A borrower may checkout books } \\
\text { from multiple reservations. }\end{array}$ & Design & $\begin{array}{l}\text { Borrower, } \\
\text { Checkout, } \\
\text { Reservation }\end{array}$ \\
\hline BRD-20 & BR-8 & $\begin{array}{l}\text { A checkout will be associated } \\
\text { with only one library card. }\end{array}$ & Design & $\begin{array}{l}\text { Checkout, } \\
\text { Library } \\
\text { Card }\end{array}$ \\
\hline BRD-21 & BR-9 & $\begin{array}{l}\text { A checkout will be associated } \\
\text { with one or more books. }\end{array}$ & Design & $\begin{array}{l}\text { Checkout, } \\
\text { Book }\end{array}$ \\
\hline BRD- 22 & BR-10 & $\begin{array}{l}\text { Deny checkout any borrowed } \\
\text { book past return date. }\end{array}$ & Logic & Checkout \\
\hline BRD-23 & BR-11 & Deny checkout if fines pending. & Logic & Checkout \\
\hline BRD-24 & BR-12 & $\begin{array}{l}\text { Borrowers can view the books } \\
\text { available online, and then } \\
\text { reserve the books for borrowing } \\
\text { or else submit an interlibrary } \\
\text { loan request. }\end{array}$ & Logic & $\begin{array}{l}\text { Book, } \\
\text { Reservation, } \\
\text { Interlibrary } \\
\text { Loan }\end{array}$ \\
\hline BRD-25 & BR-13 & $\begin{array}{l}\text { Borrowers borrow books } \\
\text { through the checkout activity at } \\
\text { Circulation desk }\end{array}$ & Logic & $\begin{array}{l}\text { Borrower, } \\
\text { Checkout }\end{array}$ \\
\hline
\end{tabular}

\section{Business Rules Derived ER Diagram PrototyPe}

The business rules specifications pertaining to database design can be transformed into database (ER) model. During the transformation (i) the business rules pertaining to terms will imply identifying the relevant attributes for the "terms" entity type, and (ii) an entity type from one business process can be expanded with inclusion of additional details for the same entity type from another business process. As there are many ER diagram notations, this paper focuses on the fork notation. For the sake of illustration only one business process (Get Library Card) is covered. Along with the ER diagram development, a sample logic aspect of business rules is illustrated through Oracle's PL/SQL language.

\subsection{Get Library Card Business Process Transformation}

The transformation of the business rules pertaining to Get Library Card business process is explained below. The associated ER model is shown in Figure 4.

- There will be two entity types borrower and library card as per BRD-1/BR-1. Further, the Registration information for the borrower may include name, address, phone number, and email address. Library card information may include card number, library center code, issue date, and customer name. 
- Since the rules description may not mention an attribute that can be an entity identifier of the borrower entity type, the attribute Borrower No is added as a primary key to the entity type. As each borrower will have only one library card (BRD-5/BR-5), the relationship between the borrower and library card is 1:1. The minimum cardinality of the relationship is also mandatory-to-mandatory since a borrower will have one library card, and the library card is only issued to one borrower (BRD-5/BR-5).

- The logic aspect of the business rules (referred by their Dictionary ID) as impacting the associated entity types is appended to the ER diagram.

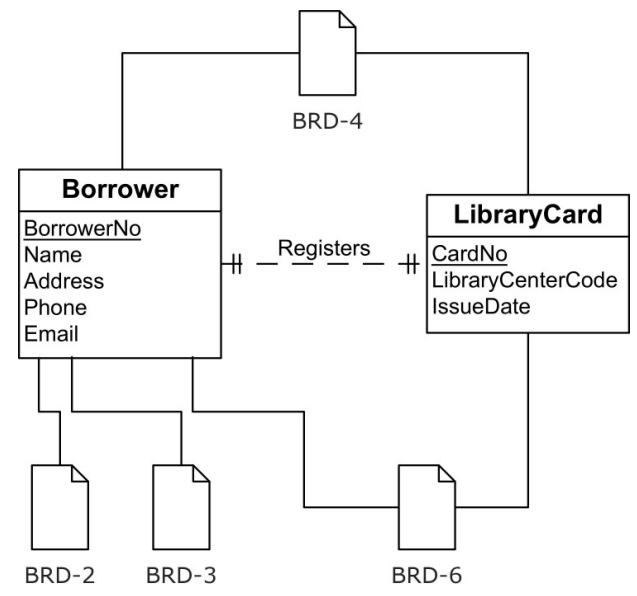

Figure 4. Get Library Card ER Model

\subsection{BuSINESS Rules DERIVED DATABASE LogiC}

The database logic component of the framework may be completed through a database procedure, function, trigger, or a package. Below is an example of a database procedure in Oracle representing Get Library Card business process business rule BRD-4/BR-4 which states that once the registration is processed a library card is issued. A sample database procedure generate_library_card will process details on the borrower and insert a row in the borrower entity type table, and then insert a row in library_card entity type table.

create or replace procedure generate_library_card (name_text in varchar2, street_text in varchar2, city_text in varchar2, state_text in varchar2, zip_text in varchar2, phone_text in varchar2, email_text in varchar2) as curr_borrower integer; curr_cardno integer; librarycentercode_text librarycard.librarycentercode\%type;

issue_date_text librarycard.issuedate\%type;

t1 varchar2(75); t2 varchar2(25); address_text borrower.address\%type; begin $\mathrm{t} 1:=$ concat(street_text,city_text); $\mathrm{t} 2:=$ concat(state_text,zip_text); address_text $:=$ concat $(\mathrm{t} 1, \mathrm{t} 2)$; insert into borrower values (borrower_seq.nextval, name_text, address_text, phone_text, email_text); select borrower_seq.currval into curr_borrower from dual;

if (zip_text = '65804' or zip_text = '65807') then 
library_code = 'SGF05';

else library_code = 'SGF10';

end if;

insert into librarycard

values (librarycard_seq.nextval,library_code,sysdate,curr_borrower);

select librarycard_seq.currval into curr_cardno from dual;

dbms_output.put_line('Registration and Library Card successful');

end;

A business application can now show a form for user to enter the data needed for a library card, and then forward the data to the database procedure generate_library_card for processing. The following is an instance of how a Web application in the form of Oracle PL/SQL Server Page [5, 15] will allow the borrower to enter their information in a Web form (Figure 5) that calls the database procedure generate_library_card, and at the end of processing the library card details are displayed also in a Web page (Figure 6).

\section{Public Library}

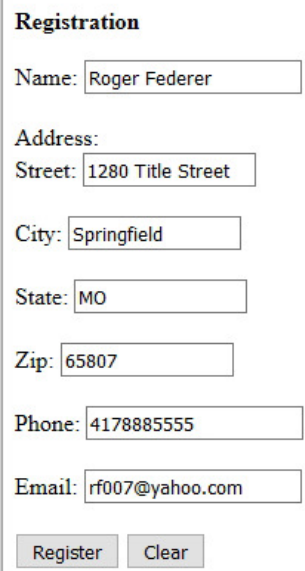

Figure 5. Borrower and Library Card Input Web Page

\section{Public Library}

Library Card(Please Print Library Card for your Records)
\begin{tabular}{|l|l|}
\hline Borrower ID: & 7 \\
\hline Card Number: & Roger Federer \\
\hline Library Center Code: & SGF05 \\
\hline Issue Date: & $01-$ SEP-16 \\
\hline
\end{tabular}

Figure 6. Library Card Details Output Web Page 
International Journal of Database Management Systems ( IJDMS ) Vol.8, No.6, December 2016

\section{CONCLUSIONS}

Database design is an essential component of any enterprise automation effort. As organizations increasingly depend on enterprise applications for accomplishing operational goals, a good database design is essential. Besides, as an organization is a collection of business processes, proper database design also influences business operations. This paper provides an outline on how to design a comprehensive database based on business processes operations.

As ER modeling focuses on the structure of data utilized by business tasks, it overlooks the operational logic associated with the database structure. This paper shows how business process derived business rules facilitate enhanced database modeling which besides facilitating the modeling of data also integrates the operational logic impacting entity types.

The paper goes beyond the traditional approaches to conceptual database design that essentially focus on database structure. Inclusion of operational logic through business rules in database model enables a more comprehensive and unified database design. The paper also illustrates how database languages can complement database design in a unified framework. Further research is ongoing on how to expand the framework to include business rules language and automation of business rules implementation.

\section{REFERENCES}

[1] Aguilar-Savén, R. S. (2004). "Business process modelling: Review and framework," International Journal of Production Economics, Vol. 90, No. 2, pp. 129-149.

[2] Allweyer, T. (2016). "BPMN 2.0: introduction to the standard for business process modeling," BoDBooks on Demand.

[3] Amghar, Y., Meziane, M. \& Flory, A. (2002). "Modeling of Business Rules For Active Database Application Specification," in Advanced Topics in Database Research, K. Siau, Ed., Hershey, PA: Idea Group Publishing, pp. 135-156.

[4] Balaban, M. \& Shoval, P. (1999). "Enhancing the ER model with integrity methods," Journal of Database Management, Vol. 10, No. 4, pp. 14-23.

[5] Boardman, S. Caffrey, M. Morse, S. \& Rosenzweig, B. (2003). "Oracle Web Application Programming for PL/SQL Developers," Upper Saddle River, NJ: Prentice-Hall.

[6] Chen, P.P. (1976). "The entity-relationship model: toward a unified view of data," ACM Transactions on Database Systems, vol. 1, no.1, pp. 9-36.

[7] Date, C.J. (2000). "What Not How: The Business Rules Approach to Application Development," Reading, MA: Addison-Wesley.

[8] Date, C. J. \& Darwen, H. (2000). "Foundation for Future Database Systems: The Third Manifesto," 2nd edition, Reading, MA: Addison-Wesley.

[9] Date, C. (2003). "Introduction to Database Systems," 8th edition, Readings, MA:Addison-Wesley.

[10] Halle, B.V. (2002). "Business Rules Applied," New York, NY: John Wiley \& Sons.

[11] Hay, D.C. (April 1, 2002). "A Repository Model - Business Rules (Action Assertions)", Data Administrator Newsletter TDAN.com (Article URL: http://www.tdan.com/view-articles/4987).

[12] Hay, D.C. (January 2002). "A Repository Model - Business Rules - Part I (Structural assertions and derivations)," The Data Administration Newsletter, Issue 19, (Available: http://www.tdan.com).

[13] Hay, D.C. (April 2002). "A Repository Model - Business Rules - Part II (Action Assertions)," The Data Administration Newsletter, Issue 20, (Available: http://www.tdan.com).

[14] Hay, D.C. (January 2004). "Modeling Busines Rules: What Data Models Do," The Data Administration Newsletter, Issue 27, (Available: http://www.tdan.com).

[15] Kaula, R. (2013). "Database Design and Application: Developing Oracle AJAX Applications with PL/SQL Server Pages," New York, NY: McGraw-Hill.

[16] Kluza, K., Kaczor, K. \& Nalepa, G.J. (2012). "Enriching business processes with rules using the Oryx BPMN editor." International Conference on Artificial Intelligence and Soft Computing. Springer Berlin Heidelberg, pp. 573-581.

[17] Lam, G. S. W. (May 2006). "Business Rules vs. Business Requirements," Business Rules Journal, vol. 7, no. 5, (Article URL: http://www.BRCommunity.com/a2006/b290.html). 
International Journal of Database Management Systems ( IJDMS ) Vol.8, No.6, December 2016

[18] Magal, S. R. \& Word, J. (2012)."Integrated Business Processes with ERP Systems,” 2nd Edition, NY: Wiley Publishing.

[19] Magal, S. R. \& Word, J. (2009). "Essentials of Business Processes and Information Systems," NY: Wiley Publishing.

[20] Mannino, M. V. (2014). "Database Design, Application Development, and Administration," Sixth Edition, Chicago Business Press, Chicago.

[21] Rob, P. \& Coronel, C. (2006). "Database Systems Design Implementation \& Management," Boston, MA: Course Technology.

[22] Polyvyanyy, A., Smirnov, S. \& Weske. M. (2015). "Business process model abstraction," Handbook on Business Process Management, vol. 1, Berlin: Springer, pp. 147-165.

[23] Ram, S. \& Khatri, V. (2005). "A comprehensive framework for modeling set-based business rules during conceptual database design," Information Systems, vol. 30, pp. 89-118.

[24] Ross, R.G. (1997)."The Business Rule Book: Classifying, Defining, and Modeling Rules," 2nd edition, Boston, MA: Database Research Group.

[25] Ross, R. (2003). "Principles of the Business Rule Approach," Boston: Addison-Wesley.

[26] Ross, R.G. (February 1, 2009). "Are Integrity Constraints Business Rules? Not!," Data Administrator Newsletter TDAN.com (Article URL: http://www.tdan.com/view-featuredcolumns/9611).

[27] Weske, M. (2012). “Business Process Management Architectures,” in Mathias Weske (Ed.) Business Process Management, Berlin: Springer, pp. 333-371.

[28] Weske, M. (2012). "Business Process Modelling Foundation," in Mathias Weske (Ed.) Business Process Management, Berlin: Springer, pp. 73-124.

[29] Zairi, M. (1997)."Business process management: a boundaryless approach to modern competitiveness,” Business Process Management Journal, vol. 3, no. 1, pp. 64 - 80. 